DOI: https://doi.org/10.36910/6775-2524-0560-2020-41-33

УДК: 006.063

Павленко Вячеслав Якович, науковий співробітник

https://orcid.org/0000-0003-0925-4173

Український науково-дослідний інститут спеціальної техніки та судових експертиз Служби безпеки України

\title{
СЕРТИФІКАЦИЙНІ ВИПРОБУВАННЯ РАДІОЕЛЕКТРОННИХ ПРИЛАДІВ В УКРАЇНІ: СУЧАСНИЙ СТАН ТА ПЕРСПЕКТИВИ РОЗВИТКУ
}

Павленко В. Я. Сертифікаційні випробування радіоелектронних приладів в Україні: сучасний стан та перспективи розвитку. У статті визначено роль та місце сертифікаційних випробувань в системі сертифікації радіоелектронних приладів в Україні. Встановлено основні особливості проведення сертифікаційних випробувань радіоелектронних приладів в Україні. Розглянуто питання проведення сертифікаційних випробувань радіоелектронних приладів у акредитованих випробувальних лабораторіях України. Сформульовано перспективи розвитку сертифікаційних випробувань радіоелектронних приладів в Україні.

Ключові слова:сертифікація, сертифікаційні випробування, радіоелектронні прилади, національні стандарти, Європейський союз, гармонізація нормативної бази.

Павленко В. Я. Сертификационные испытания радиоэлектронных приборов в Украине: современное состояние и перспективы развития. В статье определены роль и место сертификационных испытаний в системе сертификации радиоэлектронных приборов в Украине. Установлены основные особенности проведения сертификационных испытаний радиоэлектронных приборов в Украине. Рассмотрены вопросы проведения сертификационных испытаний радиоэлектронных приборов в аккредитованных испытательных лабораториях Украины. Сформулированы перспективы развития сертификационных испытаний радиоэлектронных приборов в Украине.

Ключевые слова: сертификация, сертификационные испытания, радиоэлектронные приборы, национальные стандарты, Европейский союз, гармонизация нормативной базы.

Pavlenko V. Certification tests of electronic devices in Ukraine: current status and development prospects. The article defines the role and place of certification tests in the certification system of electronic devices in Ukraine. The main features of certification test of electronic devices in Ukraine are established. The issue of conducting certification tests of radio electronic devices in accredited testing laboratories of Ukraine is considered. Prospects for the development of certification tests of electronic devices in Ukraine are formulated.

Key words: certification, certification tests, electronic devices, national standards, European Union, harmonization of regulatory framework.

Постановка проблеми. Останні роки в Україні досить активно реформується система технічного регулювання (СТР) у сфері радіоелектронних приладів (РЕП) [1] з метою гармонізації національних законодавчих та нормативних баз з Європейською базою. Реформування СТР РЕП дозволить: усунути технічні бар'єри під час взаємної торгівлі між ЄС та Україною; виробникам РЕП самостійно вибирати процедуру оцінювання відповідності; підвищувати рівень безпечності РЕП до загальноєвропейських вимог; підвищувати відповідальність заводів-виробників та постачальників за безпечність РЕП;зменшувати витрати на підтвердження нешкідливості РЕП (органами з оцінки відповідності). Прийнята угода між Україною та СС [2] підтверджує взаємну зацікавленість сторін щодо гармонізаційних процесів відповідних законодавчих й нормативних баз. Важливим питанням в сфері технічного регулювання РЕП $є$ проведення їх сертифікаційних випробувань.

Аналіз останніх досліджень і публікацій. Питанням реформування СТР продукції (i, зокрема, РЕП) присвячені багато наукових та навчально-методичних праць [1, 3-5]. В яких розглянуто певні аспекти наукових, організаційно-технічних та нормативних засад кваліметрії, стандартизації, сертифікації, акредитації та законодавчої метрології. В [3, 6-8] досить детально розкриті питання міжнародного співробітництва України 3 метою гармонізації українських стандартів 3 Європейськими. Але питання щодо сертифікаційних випробувань РЕП практично не висвітлені у вітчизняних наукових працях.

Метою дослідження $є$ визначення сучасного стану та перспектив розвитку сертифікаційних випробувань радіоелектронних приладів в Україні.

Виклад основного матеріалу дослідження. Сертифікаційні випробування РЕП за своєю сутністю $є$ контрольними випробуваннями РЕП, в результаті яких встановлюється відповідність характеристик їх властивостей міжнародній і національній нормативній документації. Контрольними випробуваннями РЕП є такі, що застосовуються з метою контролювання якості РЕП [1-3].

В статті в якості РЕП розглядаються: телекомунікаційна, навігаційна та медична техніка; високотехнологічні промислові установки; побутове електронне й електротехнічне обладнання тощо. 
Визначення ролі та місия сертифікаџійних випробувань в системі сертифікації РЕП в Україні. Сертифікаційні випробування РЕП, як правило, проводяться під час їх сертифікації. Сертифікація РЕП передбачає [9]: перевірку їх характеристик, параметрів та показників; застосування методів сертифікаційних випробувань 3 метою проведення ідентифікації (враховуючи перевірку належності до відповідних класифікаційних груп, відповідності технічної документації, місця походження, ступені приналежності до конкретної партії РЕП тощо);підтвердження відповідності РЕП встановленим вимогам.

Сертифікація РЕП в Україні здійснюється за схемами, кожна з яких містить повний набір процедур (серед яких $€$ i сертифікаційні випробування) та умов їх виконання. Схеми можуть включати одну або декілька процедур, результати яких необхідні для оцінювання відповідності РЕП заявленим до неї вимогам. Схему сертифікації РЕП пропонує заявник за погодженням з органом сертифікації. Рекомендовані схеми сертифікації продукції (i, зокрема, РЕП) наведені в [9]. Відповідно до [9] на практиці сертифікаційні випробування РЕП проводяться в рамках наступних шести основних схем сертифікації, що наведені в таблиці 1.

Таблиця 1. Основні схеми за якими проводиться сертифікація в Україні

\begin{tabular}{|c|c|c|c|c|}
\hline $\begin{array}{l}\text { Позначення } \\
\text { схеми } \\
\text { сертифікації }\end{array}$ & $\begin{array}{l}\text { Назва схеми } \\
\text { сертифікації }\end{array}$ & Сутність схеми сертифікації & $\begin{array}{c}\text { Ступінь } \\
\text { необхідності } \\
\text { проведення } \\
\text { сертифікаційних } \\
\text { випробувань } \\
\end{array}$ & $\begin{array}{c}\text { Місце } \\
\text { проведення } \\
\text { сертифікаційних } \\
\text { випробувань }\end{array}$ \\
\hline Схема 1 & $\begin{array}{l}\text { Сертифікація } \\
\text { одиничного } \\
\text { виробу }\end{array}$ & $\begin{array}{l}\text { Визначаються характеристики } \\
\text { одного або декількох зразків } \\
\text { РЕП }\end{array}$ & $\begin{array}{l}\text { Обов'язкове } \\
\text { проведення }\end{array}$ & $\begin{array}{c}\text { Акредитована } \\
\text { випробувальна } \\
\text { лабораторія }\end{array}$ \\
\hline Схема 2 & $\begin{array}{l}\text { Сертифікація } \\
\text { партії РЕП }\end{array}$ & $\begin{array}{l}\text { Визначаються характеристики } \\
\text { всієї партії РЕП }\end{array}$ & $\begin{array}{l}\text { Обов'язкове } \\
\text { проведення }\end{array}$ & $\begin{array}{c}\text { Акредитована } \\
\text { випробувальна } \\
\text { лабораторія }\end{array}$ \\
\hline Схема 3 & $\begin{array}{l}\text { Сертифікація } \\
\text { серійних } \\
\text { РЕП(3 } \\
\text { аудитом } \\
\text { виробництва) }\end{array}$ & $\begin{array}{lr}\text { Визначаються характеристики } \\
\text { одного або декількох зразків } \\
\text { серійних } & \text { РЕП } \\
\text { проведення } & \text { шляхом } \\
\text { документації } & \text { аналізу } \\
\text { процесу виробництва } & \text { стосовно } \\
\end{array}$ & $\begin{array}{l}\text { Обов'язкове } \\
\text { проведення }\end{array}$ & $\begin{array}{c}\text { Акредитована } \\
\text { випробувальна } \\
\text { лабораторія }\end{array}$ \\
\hline Схема 4 & $\begin{array}{l}\text { Сертифікація } \\
\text { серійних } \\
\text { РЕП } \\
\text { аудитом та } \\
\text { атестацією } \\
\text { виробництва) }\end{array}$ & $\begin{array}{l}\text { Визначаються характеристики } \\
\text { одного або декількох зразків } \\
\text { серійних } \\
\text { проведення } \\
\text { атестації виробництва, а також } \\
\text { випробувань }\end{array}$ & $\begin{array}{l}\text { Обов'язкове } \\
\text { проведення }\end{array}$ & $\begin{array}{c}\text { Акредитована } \\
\text { випробувальна } \\
\text { лабораторія }\end{array}$ \\
\hline Схема 5 & $\begin{array}{l}\text { Сертифікація } \\
\text { серійних } \\
\text { РЕП шляхом } \\
\text { оцінювання } \\
\text { системи } \\
\text { управління } \\
\text { якістю } \\
\end{array}$ & 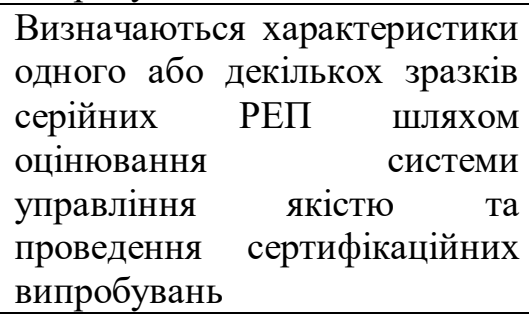 & $\begin{array}{l}\text { Обов'язкове } \\
\text { проведення }\end{array}$ & $\begin{array}{c}\text { Акредитована } \\
\text { випробувальна } \\
\text { лабораторія }\end{array}$ \\
\hline Схема 6 & $\begin{array}{l}\text { Сертифікація } \\
\text { послуг, } \\
\text { пов'язаних } 3 \\
\text { РЕП }\end{array}$ & 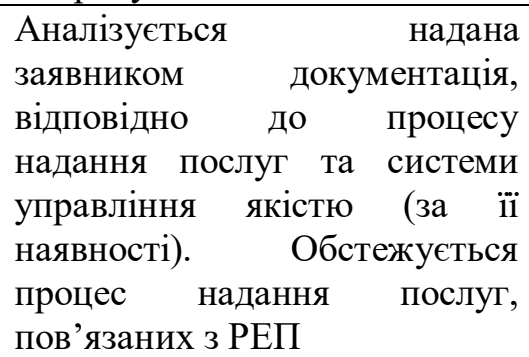 & За необхідністю & $\begin{array}{c}\text { Акредитована } \\
\text { випробувальна } \\
\text { лабораторія }\end{array}$ \\
\hline
\end{tabular}

Із таблиці 1 можна бачити, що сертифікаційні випробування $є$ важливою та практично невід’ємною складовою процесу сертифікації РЕП. 
Перевірка РЕП на відповідність встановленим вимогам залежно від обраних схем сертифікації може реалізовуватися на основі: оцінювання характеристик РЕП, процесу їх виробництва та системи управління якістю; проведення сертифікаційних випробувань РЕП та визнання результатів робіт, що були проведені органами сертифікації за кордоном (якщо РЕП іноземного виробництва).

Сертифікація РЕП з урахуванням однієї з наведених в таблиці 1 схем, як правило, передбачає виконання таких основних етапів (рис. 1) як:подання та розгляд заявки на сертифікацію та

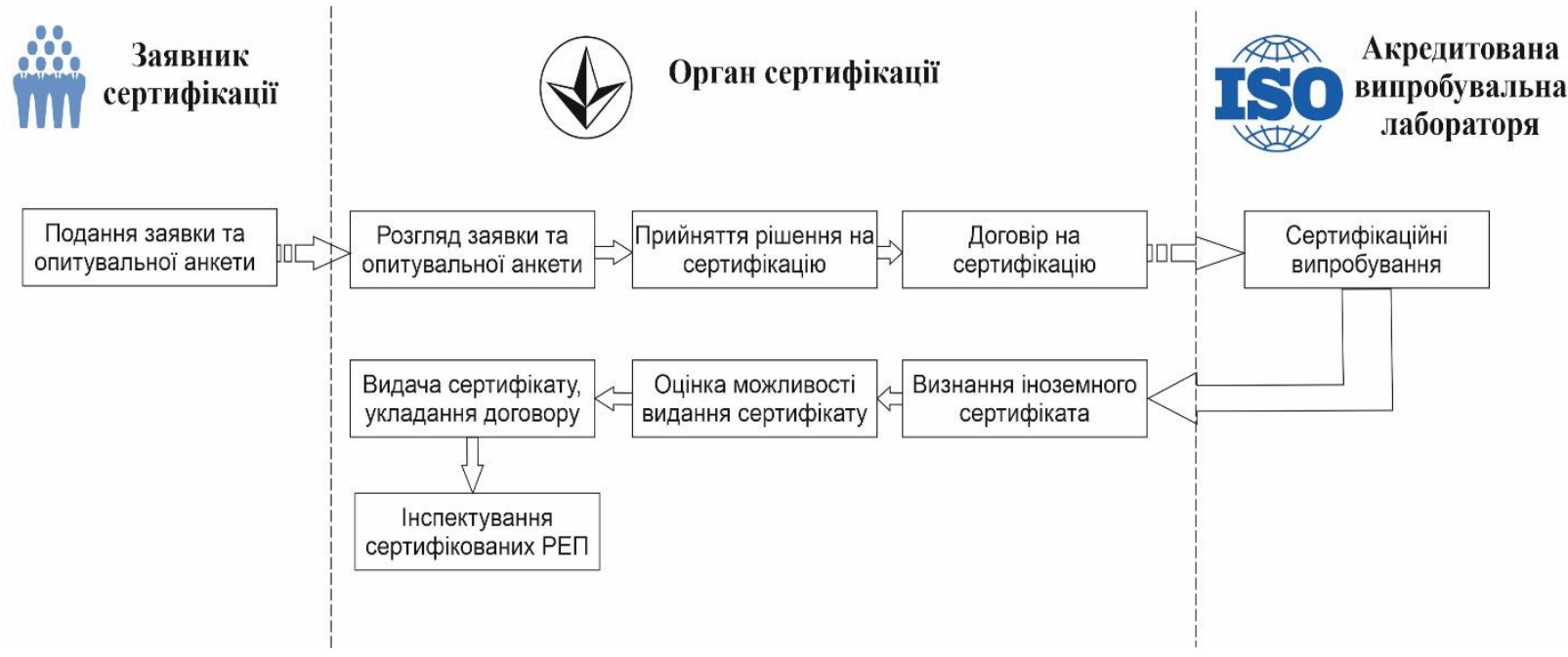

опитувальної анкети; аналіз комплекту документів, необхідних для проведення сертифікації РЕП; прийняття рішення за заявкою із зазначенням схеми сертифікації; укладання договору на проведення науково-технічних робіт з сертифікації; оцінювання на відповідність заявленим вимогам згідно 3 обраною схемою сертифікації (в тому числі аудит виробництва, оцінювання системи управління якістю РЕП, відбір, ідентифікація зразків РЕП та їх сертифікаційні випробування; визнання сертифіката, виданого іноземним органом сертифікації); аналіз одержаних результатів та прийняття рішення щодо можливості видачі сертифікату відповідності; підготовка та видача сертифікату відповідності, укладання сертифікаційного договору на право застосування сертифіката відповідності та маркування знаком відповідності та внесення інформації до Реєстру Системи УкрСЕПРО; проведення інспектування сертифікованих РЕП продукції та процесу їх виробництва та (або) системи управління якістю.

Рис. 1. Основні етапи сертифікації РЕП з урахуванням схем іï проведення

Особливості проведення сертифікаційних випробувань РЕП в Україні. Процедура сертифікації РЕП в Україні реалізується за показниками електромагнітної сумісності та показниками безпеки. Функціонування РЕП пов'язане 3 електромагнітним випромінюванням, яке створює перешкоди іншому технічному обладнанню. Наявність цих електромагнітних перешкод характеризує стан навколишнього середовища. Отже питання одночасного функціонування великої номенклатури РЕП в обмеженому просторі без електромагнітних перешкод все більше набувають актуальності. Ці питання пов'язані з безпекою РЕП, охороною праці та захистом навколишнього середовища. 3 урахуванням цього, в ЄС якщо зразок РЕП не відповідає встановленим вимогам щодо електромагнітної сумісності, то він не зможе бути реалізований на ринках $Є С$.

На сьогодні в Україні вимоги електромагнітної сумісності регламентовано цілою низкою державних стандартів та нормативних документів, що практично не гармонізовані зі стандартами СС. Таке становище в цій сфері призводить до проблем 3 визнання результатів сертифікаційних випробувань, i не може бути швидко змінено. Воно потребує вдосконалення українських нормативних документів шляхом гармонізації із нормативними Комітету СІ8РЯ,певного розподілення частотного діапазону в Україні та переоснащення акредитованих випробувальних лабораторій відповідним обладнанням. як випробувальних лабораторій промислових підприємств, так i сертифікаційних центрів. Розглянуті питання обумовлюють особливості проведення сертифікаційних випробувань РЕП в Україні.

У зв'язку 3 цим кожен рік органи сертифікації не оформлюють сертифікати на $20 \%$ імпортованих РЕП, що не відповідають встановленим вимогам щодо електромагнітної сумісності та безпеки. Крім того, більш ніж 20 \% заявникам сертифікаційні органи не проводять сертифікацію 3 
причин порушень порядку оформлення товаросупровідних документів,відсутності необхідних документів та маркування.

Акредитовані випробувальні лабораторії в Украӥні для проведення сертифікаџійних випробувань РЕП.В Україні функціонує трирівнева система сертифікації РЕП: перший рівень - це Міністерство економічного розвитку і торгівлі України; другий рівень - Державна інспекція України з захисту прав споживачів(ДП «УкрНДНЦ» і технічні комітети); третій рівень - органи з сертифікації РЕП та системи їх якості, акредитовані випробувальні лабораторії (в яких саме і проводяться сертифікаційні випробування). Отже, для сертифікаційних випробувань РЕП в Україні існують акредитовані випробувальні лабораторії, основні вимоги до яких наведено в [10-12]. Відповідно даних в [13]загальна кількість акредитованих в Україні випробувальних лабораторій складає понад 420 , серед яких сертифікаційні випробування РЕП можна проводити у 187лабораторіях. На рисунку 2 наведено діаграму розподілу у відсотках акредитованих випробувальних лабораторій для сертифікаційних випробувань РЕП в регіонах України.

Така кількість випробувальних лабораторій в Україні (рис. 2) зумовлюється: вимогами Системи УкрСЕПРО щодо проведення сертифікаційних випробувань тільки в цих лабораторіях; великою номенклатурою РЕП;жорсткими вимогами щодо оперативності проведення сертифікаційних випробувань у випробувальних лабораторіях за регіональним принципом (в межах одного із регіонів України). Обладнання таких випробувальних лабораторій, як правило, це універсальне стандартне та стандартизоване випробувальне обладнання і засоби вимірювальної техніки, що необхідні для сертифікаційних випробувань РЕП.

Серед випробувальних лабораторій особливе місце займають, такі, що сформовані на базі провідних науково-випробувальних (науково-виробничих або науково-дослідних) установ (з часів CPCP) [13].

Кількість акредитованих випробувальних лабораторій в Україні, \%

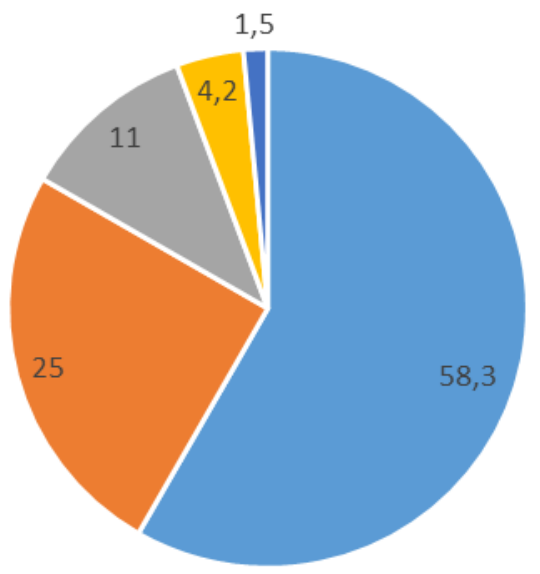

$$
\begin{aligned}
& \text { - Захід } \\
& \text { - Центр } \\
& \text { - Схід } \\
& \text { - Південь } \\
& \text { - Північ }
\end{aligned}
$$

Рис. 2. Розподілення акредитованих лабораторій для

сертифікаційних випробувань за регіонами України

В таких випробувальних лабораторіях працюють фахівці, як правило,вищої кваліфікації 3 величезним досвідом. Крім стандартизованих випробувального обладнання і засобів вимірювальної техніки, вони мають спеціалізоване, спеціальне або унікальне випробувальне обладнання (споруди, камери та стенди для випробувань), що дозволяє провести необхідні заходи щодо оцінювання й сертифікаційних випробувань значної частки номенклатури РЕП. Також вони забезпечують проведення випробувань і досліджень під час розроблення нових зразків РЕП. Такий підхід, щодо проведення сертифікаційних випробувань РЕП в одній випробувальній лабораторії суттєво зменшує терміни проведення та втрати замовників цих робіт, а також такий комплексний підхід в проведенні сертифікаційних випробувань скорочує терміни розроблення РЕП, їх постановки на виробництво i виходу на ринок.

Слід відзначити, що в існуючих випробувальних лабораторіях для сертифікаційних випробувань РЕП певна частка випробувального обладнання і засобів вимірювальної техніки $\epsilon$ застарілими та не забезпечують необхідних точності й достовірності випробувань. Також,додаткові вимоги технічних регламентів [4] та стандартів до безпеки,призводять до необхідності в 
переоснащенні(або в дооснащенні) випробувальним обладнанням і засобами вимірювальної техніки більшості випробувальних лабораторій в Україні.

Перспективи розвитку сертифікаційних випробувань РЕП в Украӥні. На сьогоднішній день вУкраїні активно реалізується практична фаза реформування СТРРЕП $[1,2,4,6]$. Основні перспективи розвитку сертифікаційних випробувань РЕП в Україні пов'язані з впровадженням технічних регламентів в сфері застосування РЕП. Організаційно-правові засади створення, прийняття i використання технічних регламентів та здійснення добровільного оцінювання відповідності продукції визначає Закон України “Про технічні регламенти та оцінку відповідності” [4].

За останні роки в державі введено понад 20 технічних регламентів щодо безпеки та енергоефективності продукції (в тому числі і РЕП). В процесі введення та впровадження в практику технічних регламентів буде відмінено процедури обов'язкової сертифікації РЕП в частині Системи сертифікації УкрСЕПРО, на яку поширюється дія технічних регламентів.

Крім того, для України найактуальнішим є підписання "Угоди про взаємне визнання Україною та ЄС сертифікатів відповідності на промислову продукцію" [14]. Підписання зазначеної угоди для України має привести до: визнання результатів роботи з оцінювання відповідності українськими органами сертифікації без додаткової процедури оцінювання відповідності в $Є С$, США,Швейцарії, Японії тощо (в цих країнах товари один одного визнаються без додаткових заходів з сертифікації); використання європейського знаку відповідності СЕ на українській продукції; тотожності вимог технічних регламентів української продукції відповідним вимогам $€ C$; взаємного визнання промислової продукції, що відповідає вимогам, згідно яких вона законно перебуває на ринку однієї зі сторін. Тільки подальші поступові кроки щодо реформування та гармонізації СТР, забезпечать українським виробникам вихід на Європейський ринок та можливість реалізовувати там свою продукцію.

Узагальнюючи вище викладене, сформулюємо основні напрямки розвитку галузі сертифікаційних випробувань РЕП в Україні:

- створення та впровадження в Україні національних стандартів - ідентичних відповідним міжнародним та європейським стандартам щодо технічних регламентів РЕП;

- заміну (чи дооснащення) випробувального обладнання та засобів вимірювальної техніки в акредитованих випробувальних лабораторіях сучасними зразками, що суттєво підвищить рівень якості їх оцінок та рівень захисту споживачів в Україні, і відповідне визнання цих результатів за кордоном;

- забезпечення високого рівня експертності працівників контролюючих органів в сфері сертифікації.

Висновки та перспективи подальших досліджень. Отже, для досягнення поставленої у статті мети, вирішено наступні часткові завдання: визначено роль та місце сертифікаційних випробувань в системі сертифікації РЕП в Україні;встановлено основні особливості проведення сертифікаційних випробувань РЕП в Україні;розглянуто питання проведення сертифікаційних випробувань РЕП у акредитованих випробувальних лабораторіях України;сформульовано перспективи розвитку сертифікаційних випробувань РЕП в Україні. Подальшим актуальним напрямком досліджень $є$ розроблення методу оптимізації сертифікаційних випробувань РЕП закордонного виробництва.

\section{References.}

1. Kozlovsky, J. (2014). Problems of transition from certification of mechanical engineering products to assessment of its compliance with technical regulations. Standardization. Certification. Quality, (3), 59-65.

2. Agreement № ENPI / 2008 / 019-594 on the financing of the project "Facilitation of mutual trade by removing technical barriers to trade between Ukraine and the European Union" (2008). URL: http://www.ier.com.ua/files/projects/2008/eu_ukraine/report_ version_for_public_debates_2008-04-02.pdf. (Last accessed: 17.03.2020).

3. Melnichuk, SD, Borovikov, O. Ya., \& Bal-Prilipko, LV (2012). Fundamentals of the system of state technical regulation: Textbook. Kyiv: NUBIP. 283 s.

4. On technical regulations and conformity assessment: Law of Ukraine of January 15, 2015 № 124-VIII. (2015). Information of the Verkhovna Rada, 14, 96.

5. Shishkin, VM, \& Chikin, SV (2017). Quality management and confirmation of conformity. Normative terminology and definitions: terminological dictionary. $308 \mathrm{~s}$.

6. Golinka, I. (2009). Development of standardization at the international, regional and national levels. Standardization, certification, quality, (1), 11-17.

7. Bal-Prilipko LV, Slobodyanyuk NM, Polishchuk GE, Paska MZ, Burak VE (2017). Standardization, metrology, certification and quality management: a textbook. Kyiv: Comprint, 2017. 571 p.

8. Zhaldak, M. (2014). European vector of metrology development. Metrology and Instruments, 5, 3-4. 
9. DSTU EN ISO / IEC 17067: 2014 (EN ISO / IEC 17067: 2013, IDT). (2014). Conformity assessment. Basic product certification provisions and guidelines for product certification schemes. Valid from 2016-01-01. Kind. ofits. Kyiv: Derzhspozhyvstandart of Ukraine. $35 \mathrm{~s}$.

10. DSTU 3412-96. (2003). State certification system UkrSEPRO. Requirements for testing laboratories and the procedure for their accreditation. Valid from 2003-03-01. Kind. ofits. Kyiv: Derzhspozhyvstandart Ukrainy, 65 p.

11. DSTU ISO / IES 17025: 2006. (2006). General requirements for the competence of testing and calibration laboratories. (ISO / IEC 17025: 2005, IDT). Valid from 2007-01-07. Kind. ofits. Kyiv: Derzhspozhyvstandart Ukrainy, 72 p.

12. DSTU EN ISO / IEC 17043: 2014. (2014). Conformity assessment. General requirements for laboratory qualification testing. (EN ISO / IEC 17043: 2010, IDT). Valid from 2016-01-01. Kind. ofits. Kyiv: Derzhspozhyvstandart Ukrainy, 89 p.

13. Choice of testing laboratory. (2020). URL: https://ukrcert.com/script/index_lab.php (Last accessed: 17.03.2020).

14. Association Agreement between Ukraine and the EU: implications for business, the population and public administration. Report of the Institute for Economic Research and Policy Consulting. (2020). URL: http://www.ier.com.ua/files/projects/2013/eu_ukraine/report_ version_for_public_debates_2013-07-01.pdf. (Last accessed: 17.03.2020). 